\title{
Obligation Versus Free Will in Khayyam's Poetry: A Linguistic and Verbal Art Theoretic Account
}

\author{
Maryam Bordbar (Corresponding author) \\ Linguistics Department, Tarbiat Modares University, Iran, Tehran \\ E-mail: mbordbar13@yahoo.com \\ Ferdows Aghagolzadeh \\ Linguistics Department, Tarbiat Modares University, Tehran, Iran \\ E-mail: aghagolz@modares.ac.ir
}

Doi:10.7575/aiac.alls.v.7n.6p.216

Received: 27/09/2016

URL: http://dx.doi.org/10.7575/aiac.alls.v.7n.6p.216

Accepted: 20/11/2016

\begin{abstract}
Although Khayyam is one of the Persian poets whose school of thought and poems are studied the most, there is hardly a research in which his intellectual system is explained and made clear via a linguistic framework. In this paper one of the most debatable matters which is "Obligation" versus "Free Will" is dealt with by using Hasan's (1989) linguistics and verbal art model. This model provides touchstones for clarifying the concepts which are foregrounded by the poet. In this study other than qualitative analysis of 33 Khayyam's quatrains which are selected based on their contents they convey, quantitative analysis method of frequency calculation is used as well. The results approve this hypothesis that the notion of "obligation" is foregrounded by linguistic tools against "Free will" as background.
\end{abstract}

Keywords: functional linguistics; free will; obligation; Khayyam's poetry

\section{Introduction}

A kind of obligation is prominent in Khayyam's quatrains which helps man to be happy in his life and though difficult, enjoy it in some way. This viewpoint is quite justifiable in an era that freedom of thought and expression of one's ideas are restricted. This requirement for artificial happiness leads man to denotative or connotative ${ }^{1}$ wine. As a matter of fact, regarding the social circumstances the obligation makes man choose between two different ways of living that is with happiness and thoughtlessness or grief and worriedness. So, this is the man who chooses his way with Free Will.

It can be said that man's Free will sit alongside of God's obligation. This fact that Khayyam was Ash'arite, can justify his emphasis on "Obligation" over "Free Will" in different historical research about him. When Mohio-1-din Sabri asked Khayyam that "which sect do you consider more correct, Jabriyeh (in which man is not of Free will) or Qadriyeh (in which man is free in his action)? Khayyam said "maybe the Jabries unless they fall in suspicions and deliriums and exaggerate, for when they inclined to exaggeration and hyperbole they will retreat from the truth. (Rezazadeh, 1995)

In this paper, the researchers are going to investigate the foregrounding techniques that Khayyam used in his quatrains based on Hasan's Functional Linguistics (1989) framework. Tense, opposition, repetition, parallel structure, modality, and thematization are some of the foregrounding tools which are analyzed in the quatrains. It is hypothesized that the use of this stylistic tools clarifies and supports Khayyam's standpoint on "Obligation" and "Free will".

\section{Literature Review}

Although many studies are conducted about Kayyam's quatrains and his way of thinking by now, no one tried to investigate foregrounding of a concept using linguistic tools and based on Hasan's Functional Linguistics (1989) framework.

Zare-behtash (1994) in his doctoral dissertation tries to demonstrate that Fitzgerald more invented than translated Khayyam's quatrains. That is, the translation does not match Khayyam's point of view but Fitzgerald's own way of thinking. Zare-Behtash believes that representing Omar Khayyam as a sufi in one line and as a nihilist in the other is far from reality.

1 "Wine" is considered by Graves as a metaphor for divine love. 
Investigating Khayyam's philosophy on humanity, Erfani (1996) tries to prove that all the quatrains which are said to be suspiciously Khayyam's, are very likely to be his own quatrains. He believes that no one else could have recited them.

Niksirat (2001) in his paper investigates the matter of obligation and Free will as an important and to some extent ambiguous aspects of Khayyam's beliefs and ideas about obligation and Free will based on historical books and documents and not on the quatrains. All the discussion in this paper led to this conclusion that he believes more in obligation than in Free will as Ash'arite's view. Although Niksirat doesn't get to this conclusion via analyzing Khayyam's quatrains, he stipulates that the quatrains witness Khayyam's obligatory viewpoint as well.

Amin (2008) investigates faith versus blasphemy in Khayyam's quatrains. He divides the research on this matter into two groups. The first group believes that the blasphemous quatrains are highly unlikely to be recited by Khayyam. The other group, whose pioneer is Hedayat, emphasize on Khayyam's impiety and blasphemy and make him known as a pure atheist. Amin, by presenting numerous proofs, demonstrates that Khayyam like any other scholar could accept traditional beliefs of his society and meanwhile he doubts and hesitates in the beliefs especially when he is going to picture his poetic thought.

Fazeli (2008) inquires into the characteristics of Khayyam's school of thought by a phenomenological investigation. Considering the contents and common ideas of the quatrains Fazeli divided Khayyam's intellectual system into five main category. He then analyzed Khayyam's prior message in each category representing witnesses from the quatrains.

Hasanli and Hesampour (2010) collect and investigate all studies that was conducted about Khayyam and his quatrains in fourth century. They divide this era to before 1300 (solar year) and after that. Before 1300 there are too many contradictory beliefs about Khayyam in old documents and sources. Studies after the year 1300 are however effected greatly from Fitzgerald's translation of the quatrains. This translation not only attracted the world's attention to Khayyam but also motivated Iranian researchers to pay a closer look at Khayyam's life and personality.

Sharif and Yarmohammadi (2014) critically analyze 40 Khayyam's quatrains using Yarmohammadi's (1391) discourse analysis model. The results shows that among the discourse components in the aforesaid model, expression with tenor symmetry is significantly more frequent than expression with verbal symmetry. This investigation demonstrates that Yarmohammadi's model which is inspired by Van Leeuwen (1996) critical discourse analysis is efficient in analyzing Persian literary texts and more specifically poems.

\subsection{Theoretical Framework}

Hasan (1989) introduces her model in the book linguistics, language, and verbal art. Foregrounding, in Hasan's Functional Linguistics (1989) view is patterned based on the notion of contrast. A consistent background is necessary for foregrounding. Textual features are being foregrounded only if they sit against the background. As a matter of fact foregrounding oppose the norms of the text. This tool is used to carry deeper meanings of the text and highlight the message of the poet.

Hasan, in her book applied the stylistic tools that are of help in recognition of the concepts which are foregrounded. She discusses about repetition and contrast, parallel structures, logical relations and selection of tenses, -er roles and ed- roles, transitivity function and passivization.

\section{Method}

The researchers investigate 121 quatrains which has been authenticated by Christensen, and chose 33 that deal with obligation and free will. There were 29 quatrains that contain obligation, four that contain free will, and four that include both. The quatrains are first qualitatively investigated so that contents that convey the notion of obligation and free will are categorized. Afterwards, the quatrains are analyzed based on criteria like tense, parallelism, repetition. Contrast, thematization, and modality to see how they are utilized for foregrounding and do their application approve the hypothesis of obligation being foregrounded over free will as background. The researchers made use of quantitative analysis method of accounting frequency.

\section{Results}

There are 33 quatrains in which the notions of obligation and/or Free will are observed. The researchers investigate them based on different foregrounding tools Hasan (1989) represented. eight elements of time, meaning and wording contrast, repetition, parallelism, modality, thematization, and -er roles were contrastively analyzed in couplets with obligation or Free will to see which one could be said to sit as the background and which one is of more importance to the poet as foreground.

But, before this analysis, presenting the contents which are implied by the notions of obligation and Free will may give the reader an insight and facilitate following the investigation. The notion of obligation is associated with 1. Divine decree and predestination, 2. Looking at sweetheart beauty (symbolizing sin), 3. Birth and death, 4. Fate, 5. Future events, 6. Living with difficulty and grief, 7. The amount of man's sustenance and lifetime, 8. All the steps that a man takes in his life (all his decisions in life) 
On the other hand, Free will is associated with aberration and drunkenness, happiness, choosing religion, and solving mundane problems. Not only the number of quatrains with Obligation is more than this number with Free will, but also obligation in these quatrains attributes to more phenomena than Free will.

\subsection{Tense}

The table below shows the distribution of different tenses in the quatrains with obligation and free will.

Table 1. distribution of different tenses in the quatrains with obligation and free will

\begin{tabular}{llll}
\hline tense & past & present & future \\
\hline obligation & 8 & 21 & 3 \\
\hline Free will & 2 & 5 & 0 \\
\hline
\end{tabular}

Most of the tenses is in the present that witness Khayyam's emphasis on living in the present and not thinking of future which hasn't come yet and past which is gone. In general the ratio of the tenses in two kinds of quatrains are the same.

\subsection{Meaning Contrasts}

Meaning contrast is only observed in the quatrains with the notion of obligation. Four different kinds of contrast are seen in the table below:

Table 2. meaning contrast in the quatrains with obligation

\begin{tabular}{llll}
\hline 3 & Happiness (first couplet) & Vs. & Death and nonexistence (second couplet) \\
\hline 3 & Grief and sorrow (first couplet) & Vs. & Helpless death so living happily (second couplet) \\
\hline 1 & Happiness (first 3 hemistiches) & Vs. & Fate and helpless meanness (last hemistich) \\
\hline
\end{tabular}

In two cases obligation (in death) is contrasted to Free will (in happiness) in two couplets.

Contrast in wording level seems to be more frequent in quatrains with Free will (75\%) than quatrains with obligation (50\%). Among the 15 wording contrasts in obligation-based quatrains, nine are placed in the last hemistich and the other six in the first couplet. The placing of the six contrasts in Free will-based quatrains is quite different since except the one in the last hemistich the other five are distributed in the other three hemistiches.

\subsection{Repetition}

Dealing with the repetition in the quatrains, the researchers put the rimes aside because other than the rimes which are presented in almost all the quatrains, 39 words are repeated and their repetition seems not to be focused in one place or the other. That is, the frequency and distribution of the repeated words are about the same in both the quatrains with obligation and Free will.

\subsection{Paralellism}

Nevertheless, the parallel structures in the quatrains with free will are more outstanding than them in the other quatrains. Three quatrains out of five with Free will contain parallel structures. This number in all the 29 quatrains with obligation is only seven. The parallel structures are observed in different places like the first couplet as in

$$
\begin{gathered}
\text { وز خوردن آدمى زمين سير نشد } \\
\text { v-az xordane ãdami zamin sir našod }
\end{gathered}
$$

ta'jil makon ham bexorad dir našod

$$
\text { بر جرخ فلك هيج كسى جير نشد }
$$

bar carxe falak hic kasi cir našod

$$
\text { مغرور بدانى كه نخوردست تر ا }
$$

maqrur bedãni ke naxordast to rã

Or the second couplet as in:

جز خوردن غصه نيست تا كندن جان

joz xordane qosse nist tã kandane jãn

و آسوده كسى كه خود نبامد به جهان

v-ãsude kasi ke xod nayãmad be jahãn

$$
\text { جون حاصل آدمى در اين شورستان }
$$

con hãsele ãdami dar in šurestãn

$$
\text { خرم دل آنكه زين جهان زود برفت }
$$

xorramdel ãnke z-in jahãn zud beraft

Or the second hemistich of the first couplet with the first hemistich of the second couplet as in:

$$
\text { كردم همه مشكلات كلى را حل }
$$$$
\text { از جرم كل سياه تا اوج زحل }
$$

kardam hame moškelãte kolli rã hal az jerme gele siãh tã owje zohal 
هر بند كثاده شد به جز بند اجل

har band gošãde šod bejoz bande ajal

Or between the two phrases in the last hemistich as in:

$$
\text { سرمست بدم كه كردم اين اوباشى }
$$

sarmast bodam co kardam in owbãši

$$
\text { من جون نو بدم تو نيز جون من باثشى }
$$

man con to bodam to niz con man bãši

Or even are scattered in the whole quatrain as in:

$$
\text { خو اهى نو فلى هفت شمر خو اهى هشت }
$$

xãhi to falak haft šemor xãhi hašt

$$
\text { جه مور خورد به گُور و جهه گرگ به دشت }
$$

ce mur xorad be gur o ce gorg be dašt
بكثادم بندهاى مشكل به حيل

bogšãdam bandhãye moškel be hial

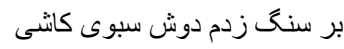

bar sang zadam duš sabuye kãši

$$
\text { با من بهزبان حال مى كفت سبو }
$$

bã man be zabãne hãl migoft sabu

$$
\text { جون جر خ به كام يك خردمند نكثت }
$$

con carx be kãme yek xeradmand nagašt

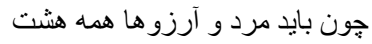

con bãyad mord o ãrezuhã hame hašt

\subsection{Modality}

Analyzing the modality of the sentences in both kinds of quatrains results in the following table:

Table 3. modality in sentences with obligation and free will

\begin{tabular}{lllll}
\hline & Imperative & Conditional & Declarative & interrogative \\
\hline obligation & 11 & 6 & 35 & 11 \\
\hline Free will & 1 & 1 & 8 & 1 \\
\hline
\end{tabular}

It goes without saying that unlike the declarative and conditional moods which are of the same frequency in free will-based quatrains and obligation-based ones, this is not the case with the interrogatives and imperatives. The percentage of these two moods in free will-based quatrains in comparison with obligationbased quatrains is $12 / 5 \%$ to $38 \%$.

\subsection{Thematization}

The researchers couldn't count on thematization for foregrounding considering the similar frequency the process in two kinds of quatrains. Nine cases of thematization in obligation-based quatrains and two in Free will-based quatrains and their similar placing cannot cause any distinction between them in choosing one as background and the other as foreground.

\section{7 -Er Roles}

One more thing that is important to be taken into consideration is "-er role". Table (5-4) demonstrates the actors in both the quatrains with obligation and free will.

Table 4. actors in quatrains with obligation and free will

\begin{tabular}{llll}
\hline Obligation & & Free will & \\
\hline You & 3 & I & 3 \\
\hline God & 5 & Libertine & 1 \\
\hline Saqi & 1 & Nation & 1 \\
\hline world & 1 & &
\end{tabular}

The only actor in the quatrains with obligation is "God" who is addressed by different titles (God, you, saqi, etc.). In the quatrains with free will the main actor is "I" but occasionally third parties like "a nation" and "a libertine" are as well employed.

\section{Discussion}

Despite the fact that the quality and quantity of some criteria like tense, thematization, and parallelism were pretty much the same in two aforesaid kinds of quatrains but other stylistic tools made significant differences between them.

First, other than the meaning contrast between free will and obligation in the first and the second couplets, this contrast is not seen in the quatrains with Fee will but only in the obligation-based quatrains. As in table 5-2 various contents like happiness and death, grief and happiness, and happiness and fate are contrasted to each other in these quatrains. 
The second criterion that is different among two under discussion types of quatrains is contrast I wording level. Though the number of contrast is not highlighted in any of the quatrains with obligation or free will, the position of nine wording contrasts out of 15 in obligation-based quatrains could be meaningful by itself.

The number of repetitions could be considered as the third criterion which make significant difference. The percentage of repetition in quatrains with obligation is $117 \%$ while this number in free will-based quatrains is $40 \%$. As it was mentioned before, (section 5-5) the imperative and interrogative moods are more frequently used in the quatrains with obligation than in the other quatrains. The -er role was also foregrounded in these quatrains by attributing various epithets to a single actor.

\section{Conclusion}

As the concepts associated with the notions of obligation and free will, the results do not demonstrate partiality in one of these notions. One cannot consider absolute obligation or free will in Khayyam's quatrains. All the stylistic tools were employed to foreground obligation or free will. More over the difference in using the other tools was hardly significant. That is, the foregrounded obligation did not make the reader lay free will aside. As it is inferred by the words which carry the content of obligation and free will, most of the events in man's life is obligatory but still he has the opportunity to choose in his religion and way of thinking.

\section{References}

Amin, H. (2008). The contrast between faithand blasphemy in Khayyam's quatrains. Collection of articles: Internal Journal, 55, 12-16.

Arberry, A. J. (1952). Omar Khayyam: A new version based upon recent discoveries.London: John Murray.

Dashti, A. (2011). In search of Omar Khayyam. London and New York: Routledge Taylor and Francis group.

Dehbashi, A. (2007). Rubaiat of Khayyam. Tehran: Gooya Publication.

Erfani, F. (1996). Khayyam's philosophical humanism. Chista, 126, 480-486.

Fazeli, M. (2008). Khayyam's intellectual system. Literary Research, 20, 61-89.

Hasanli, K., Hesampour, S. (2009). The history of research on Khayyam in fourteenth century. Persian Language and Literature Periodical, 14, 99-126.

Niksirat, A. (2001). Khayyam and the problem of obligation and free will. Kheradnameye Sadra, 25, 84-91.

Rezazade, A. (2001). Khayyamname. Azam-e-Bonab Publication, 1, 8-10.

Sasani, F. (2000). Understanding Khayyam's Quatrains, the way poetry interpretation forms. Aesthetics, 2, 117-124.

Seyyed-Gohrab, A.A. (2012). The great Umar Khayyam, a global reception of the rubáiyát. Leiden University Press.-

Zare-Behtash, E. (1994). FitzGerald's rubáiyát: A victorian invention (doctoral dissertation). Retrieved from https://digitalcollections.anu.edu.au/bitstream/1885/49275/4/02whole.pdf

Yarmohammadi, L., Sharif, M. (2014). Investigating Khayyam's quatrains through critical discourse using discourse-based semantic and sociological components. Literature Garden, 6(2), 67-82. 